\title{
甲状腺原発扁平上皮癌の一症例
}

\author{
大平 真司・有賀 秀治・石田＼cjkstart稔* \\ 吉原 渡**
}

\section{Primary Squamous Cell Carcinoma of the \\ Thyroid Gland; a Case Report}

\author{
Shinji Ohhira, Hideharu Aruga, Minoru Ishida \\ and Wataru Yoshihara
}

(Suita Municipal Hospital)

This report describes the diagnosis and treatment of a 73-year-old woman with squamous cell carcinoma of the thyroid gland.

1) Primary squamous cell carcinoma of the thyroid gland is very rare, accounting for about $1.1 \%$ (Goldman) of all malignant tumors of the thyroid gland.

2) We detected neither papillary adenocarcinoma nor squamous cell dysplasia of the thyroid gland which might be precursors of squamous cell carcinoma.

3) Squamous cell carcinoma of the thyroid gland does not respond to either Pepleomycin or radiation therapy, and the prognosis is very poor.

\section{緒言 言}

甲状腺原発の悪性腫瘍は乳頭状腺癌が抆も多く，40６0\%を占めている ${ }^{11}$ が，原発性扁平上皮癌 は極めて稀なむのであり，その発生母地について種々の説が述べられている．今回，甲状腺原発の 扁平上皮癌の 1 症例を経験し, 若干の文献的考察を加えて報告する.

症

患 者: 73歳, 女性

既往歴・家族歴：特記すべきことなし。

現病歴：昭和58年11月末以来，咽頭痛，扰よ び軽度呼吸困難あり，近医内科にて喘息として 治療を受けていた。次第に呼收困難増強し, 與 下痛強く, 食慨の摂取困難のため, 昭和 59 年 2 月 3 日, 当科に緊急入院となる.
例

入院時所見 : $37^{\circ} \mathrm{C}$ 台の微熱. 間接喉頭所見は 図 1 のように，左披裂喉頭蓋ヒダから喉頭蓋に かけて発赤, 浮腫状腫脤がみられ声带は観察し 得なかった。前頸部腫瘤は特に触知せず。

血液検查: 白血球 10100 , 赤血球 $366 \times 10^{4}$, 白血球分類（杵状球 $3 \%$, 分葉球 $73 \%$, リンパ 球 $22 \%$, 単球 $2 \%$ ), 血沈（1 時間值 $78 \mathrm{~mm}, 2$

\footnotetext{
*市立吹田市民病院耳鼻咽喉科

**同上病理部
} 


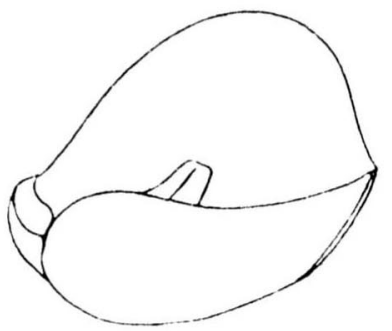

図 I 閣接喉頭鏡検査

左披裂喉頭蓋ヒダから喉頭蓋にかけて発赤, 浮腫 状腫脹し，声帯は望見困難である。

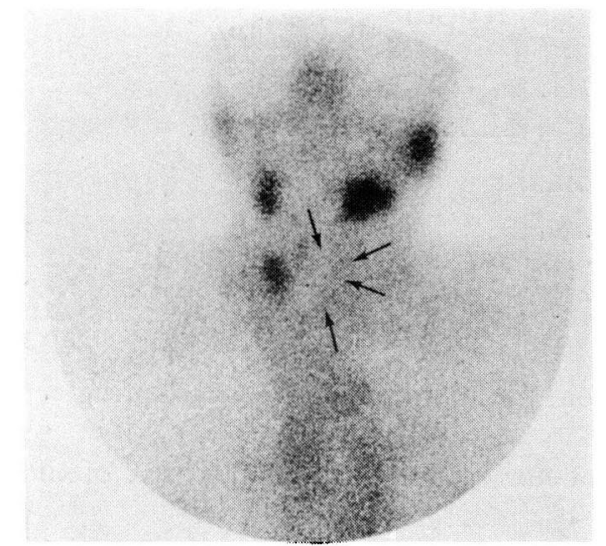

図 2 甲状腺は右葉の一部を除いて左葉から峡部 にかけて陰影欠損を認めた（矢印）.

時間 $121 \mathrm{~mm})$.

血清検查：CR P $(3+)$, GOT61, G P T81, L D H554, を除いて正常.

甲状腺機能検查：トリオソルブ $27 \% ， \mathrm{~T}_{4} 2.2$ $\mu \mathrm{g} / \mathrm{dl}, \quad \mathrm{T} \mathrm{S} \mathrm{H} 13.0 \mu \mathrm{M} / \mathrm{ml}, \mathrm{T}_{3} 0.3 \mathrm{ng} / \mathrm{ml}$,

甲状腺シンチ：甲状腺左葉から峡部にかけて の陰影欠損をみとめた（図 2 ）。

頸部 CT-scan：甲状腺左葉に一致して low density の腫瘤陰影，およびそれによる気管の 压排をみとめた。また，左葉に一部リング状の high density を伴う cyst 椂㓌影をみとめた (図 3 ).

手術洔所見：甲状腺左葉は，図4のように全 体的に弾性硬の腫瘍におきかわり，頭側は甲状 軟骨，左側方向へは左葉周囲結合織，右側方向

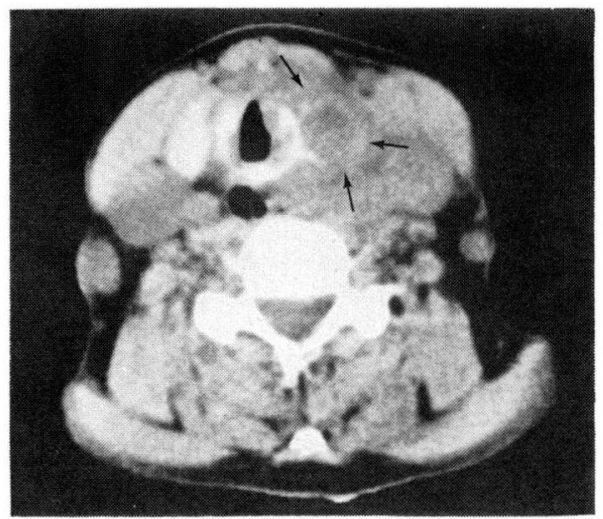

図 3 甲状腺左葉に一致して Low density の腫熘陰影，およびそれによる気管の 圧排を認めた．左葉に一部リング状の high density を伴う cyst 様陰影を みとめた（矢印）。

〔手術所見〕昭和59年 2月6日

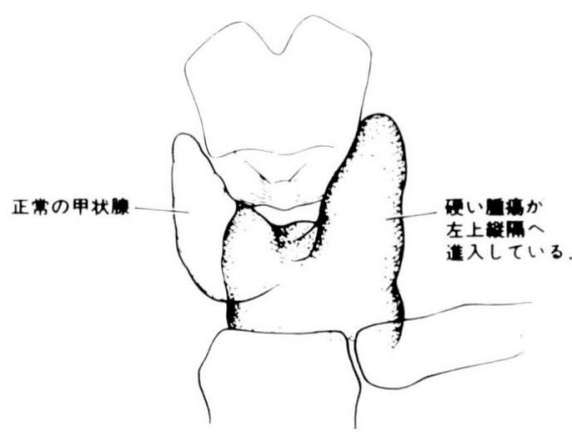

图 4 甲状腺左葉は全体的に弾性硬の腫焬におき かわり，頭側は甲状軟骨左側方向へは左葉 周网結合織，右側方向へは右葉の一部，尾 側方向へは上縦隔内へと進展していた。

へは右葉の一部, 尼側う向へは上縦隔内へと進 展していた。腫煬塊をできる限り切除し気管切 開を行なった。

入院後経過：入院後次第に呼吸困難増強し, 緊急気管切開施行. 術後放射線治療 $4000 \mathrm{cGy}$, さらにペプレオマイシン $10 \mathrm{mg}$ 週 2 回静注（総量 100mg）するも効果なく，前頸部および顔面腫 脹, 左ホルネル症候群が出現し, また胸部レ線 


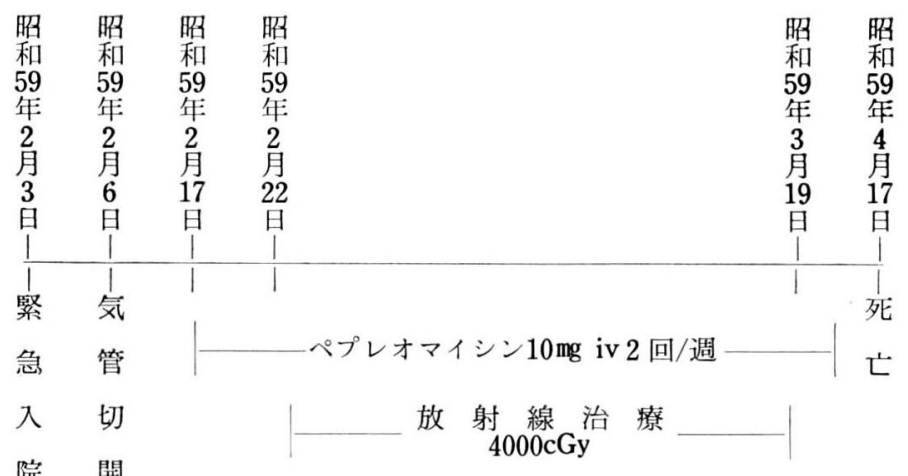

図 5 入院後治療および経過

表 I 病理解剖所見

\section{〔主病変〕}

甲状腺癌術後状態（扁平上皮癌）

1 気管壁への直接浸潤

2 両肺転移, 癌性胸膜炎

3 右心室壁への転移

[副病変〕

1 気管支肺炎（右下葉に強い）

2 心筋内カンジダ症

3 左総頸静脈の血栓形成

にて左胸水眝溜, 両側肺炎像がみられ, 次第に 意識レベルも低下し，入院後約 3 力月余りの経 過で呼吸不全にて死亡した（図 5 ).

病理解剖所見: 肉眼的な病理学的所見は, 表 1，および図 $6 〜 7$ に示す.

病理組織学的所見: 甲状腺実質は広籁に破壊 され, 角化傾向を伴う比較的よく分化した扁平 上皮癌が nest を形成して存在し，一部には癌 真珠の形成むみられる（図 8 ). 左気管上部び らん部の組織像であるが, 扁平上皮癌の浸潤が あり壊死脱落している(図 9 ).

考

甲状腺に原発する悪性腫湯は乳頭腺癌がもっ とも多く，扁平上皮癌はわずか $1.1 \%$ (Gold$\operatorname{man})^{2)}, 0.3 \%$ (甲状腺外科検討会, 1977

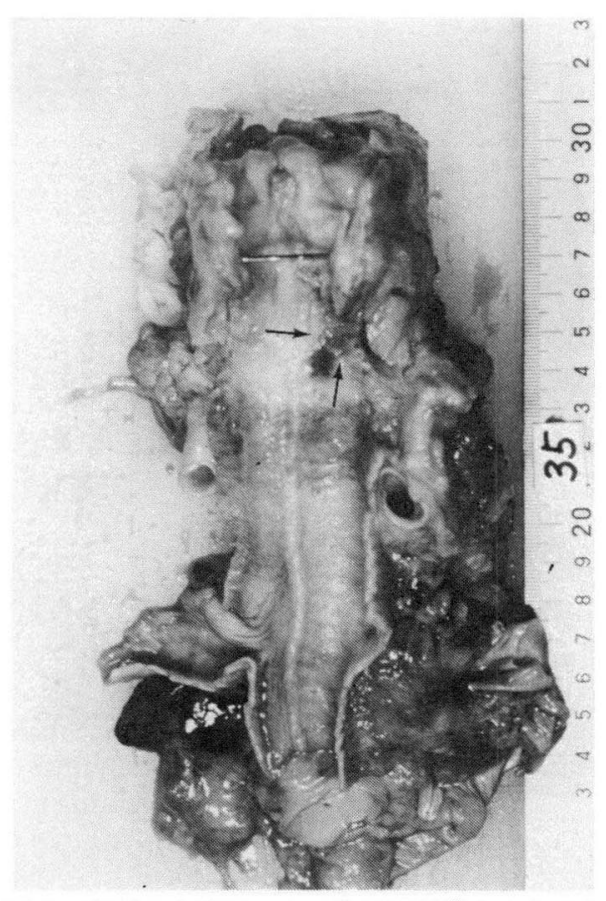

図6 喉頭は上皮にマク口的には異常をみとめな いが，気管は左上部にマクロ的にびらんを 認めた (矢印).
察

1980年) $)^{3)}$ にすぎないと報告されている。 ま た，甲状腺は気管，食道，喉頭に隣接してお り，これらの領域には扁平上皮癌が多いことか 


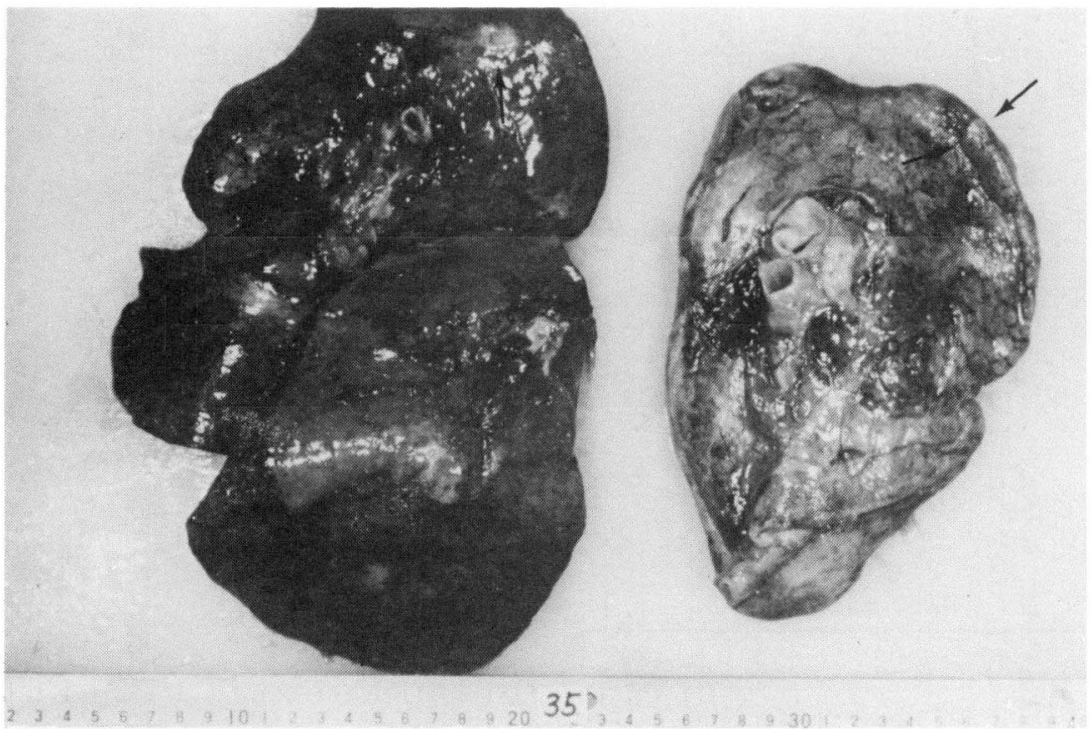

図 7 両肺とも浮腫状で, 胸膜の肥厚をみとめ気管支肺炎, 癌性胸膜炎の所見である. また両肺に白い結節状の転移巣をみとめる (矢印).

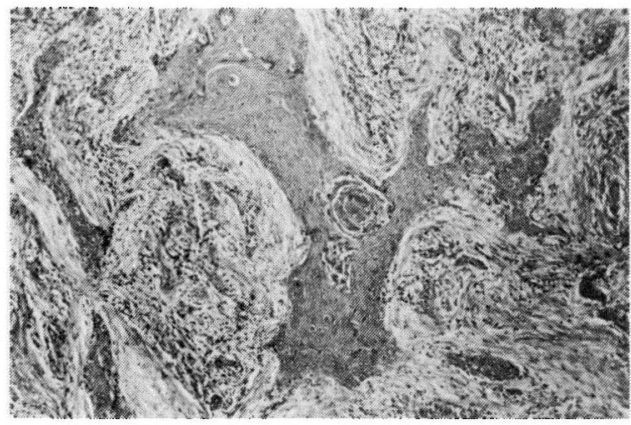

図 8 甲状腺実質は広範に破壊され，角化傾向を 伴う比較的よく分化した扁平上皮癌が nest を形成して存在し，一部には癌真珠の形成 もみられる.

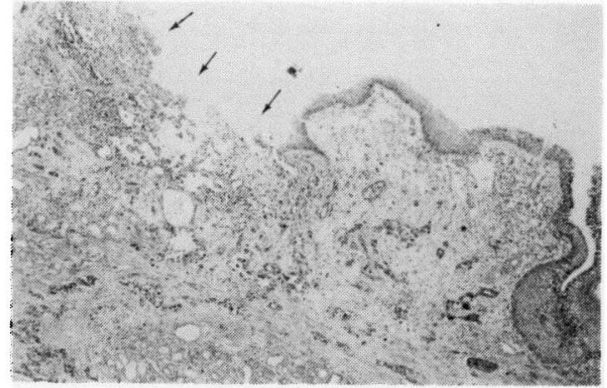

図 9 気管左上部びらん部の組織像であるが，頸 部腫熘と同じ扁平上皮癌が露出し，壊死を 伴っている (矢印)。びらん周井の上皮に は，異形成から上皮内癌に至る異常はみ之 められない.
ら，甲状腺の扁平上皮癌に遭遇して屯，乙れが 原発性のものか続発性のものかを鑑別するこ とが大切であり，また同時に原発性と診断する には大変揁重を要する．本症例でむその点が問 題となり，喉頭および食道はマク口的にもミク 口的にも上皮に異常はなく完全に否定できる が，気管については図 6 のように左上部でマク 口的にびらんがあり，また図 9 のように組織学
的にも頸部腫瘤と同じ扁平上皮癌が露出し, 塤 死を伴っている．ここで問題となるのは甲状腺 癌が気管に浸潤したものか, 気管癌が甲状腺へ 浸潤したむのかということである，文献年によ ると, 気管原発の扁平上皮癌は全例気管内内腔に 腫瘤状発青をすることがいわれているが, 本症 例では腫㾔形成はなく軽度のびらんを形成して いた。またびらん周囲の気管粘膜には，異形 
成から上皮内癌に至る上皮異常をみとめなかっ た。以上の点から，父得原発ではなく甲状腺原 発の扁平上皮癌と考え，それが気管にまで浸潤 したもの之診断した。

甲状腺にみられる唡平上皮紐胞の内来につい ては，以前では後鰓管体 ${ }^{51}$ や甲状舌管"6) などの 胎生期の遺残物に基づくとする説が有力であっ たが，今日では一般に甲状腺の沪胞上皮よりの 化生であると考えられている ${ }^{7) 10)}$ 。こして, 甲状腺の扁平上皮化生は甲状腺の病的状態，す なわち乳頭癌 ${ }^{11)}$, 腺腫㥞甲状腺腫 ${ }^{1112)}$, リーデ ル甲状腺腫 ${ }^{13)}$, 慢性甲状腺炎 ${ }^{7)}{ }^{9)}$, 囊胞 ${ }^{97}$, 転移 性腫瘍 ${ }^{7)}$ ，腺腫 ${ }^{10)}$ などにおてったむのが報告さ れているが, 甲状腺の扁平上皮癌は，この扁平上 皮化生から生じると考えられている。 Jaffe ${ }^{7)}$,

Saxen ${ }^{10)}, G^{\prime}$ oldman ${ }^{12)}$ は，沪胞上皮の扁平上: 皮化生と扁半上皮嵒の合併を観祭し，その移行 を示唆している。 また, Dube \& Joyce ${ }^{13)}$ は 乳頭腺癌の症例を追跡して, 腺癌から悪性扁平 上皮が出現した数例を経験したと述べている。 われわれの症例では扁平上皮癌のみで, 扁平上 皮化生，乳頭腺癌の合併はなく，その発生機転 については全く不明である。また，慢性甲状腺 炎や甲状腺腫などの既往症むなかった。

甲状腺の扁平上皮癌の予後について種々の報 告14)-16) があるが，一般に予後不良である。乙 の症例でも，ペプレオマイシン，放射線治療に て全く効果なく, 入院後 3 力月余りで死亡し た.

\section{語}

73歳久性の甲状腺原発扁平上皮癌の 1 症例を経験し，文献的考察を加え報告した。その特徵をま とめると以下の様になる。

1 ）甲状腺原発扁平上皮癌は，全甲状腺墨性腫瘍の $1.1 \%$ （Goldman）程度と，大变稀なむので ある。

2 ）扁平上皮癌の発生機転を示唆するような, 扁平上皮化生, 乳頭腺癌などの合併はみとめなか った.

3 ）ぺプレオマイシン，放射線治療には全く感受性なく，予後不良である.

文

1) 大波勇, 亀谷道男, 他：甲状腺扁平上皮癌につい て, 癌の臨床 $8: 544 \sim 547,1962$.

2 ) Goldman RL : Primary squamous cell carcinoma of the thyroid gland: Report of a case and review of the literature. Amer Surg $30: 247 \sim 252,1964$.

3 ）草間 悟, 和田達雄, 他：甲状腺癌概説, 外科 Mook 27 甲状腺 -上皮小体の外科：165 171, 1982.

4) Steven I, Hajdu MD, Andrew G, Huvos MD : Carcinoma of the trachea. Cancer June $25: 1448 \sim 1456,1970$.

5) Van Dyke JH: Behavior of the Ultimobranchial tissue in the Postnatal thyroid gland : origin of the thyroid cystadenoma in

\section{献}

rat. Anat Rec 88:369 391, 1944.

6 ) Goldberg HM \& Harvey P : Squamous-cell cysts of the thyroid with special reference to the aetiology of squamous epithelium in the human thyroid. Brit J Surg $43: 565 \sim$ $569,1956$.

7) Jaffe RH: Epithelial metaplasia of the thyroid gland with special reference to histogenesis of squamous cell carcinoma of the thyroid gland. Arch Path $23: 821 \sim 830$, 1937.

8) Boyden AM, et al : Riedel's struma. West J Surg $43: 547 \sim 563,1935$.

9) Harcourt-Webster JN : Squamous epithelium in the human thyroid gland. $\mathrm{J}$ Clin 
Path 19:384 388, 1966.

10) Bullock WK, et al: Squamous metaplasia of the thyroid gland. Cancer $5: 966 \sim 974$, 1952.

11) Klinck HG \& Menk KF : Squamous cells in the human thyroid. Milit Surg 109:406 414, 1951.

12) Goldman RL : Primary squamous cell carcinoma of the thyroid gland: Report of a case and review of the literature. Ameri Surgeon $30: 247 \sim 252,1964$.

13) Dube VE \& Joyce GH : Extreme squamous metaplasia in Hashimoto's thyroiditis. Cancer $27: 433 \sim 437,1971$.
14）宮川信, 関 龍幸, 他: 甲状腺原発の扁平上:皮 癌. 癌の臨床 I9 ( 3 ): 193〜200, 1973.

15）原田種一, 松土昭彦, 他: 甲状腺乳頭腺癌の扁平 上皮化生および扁平上皮癌合併について. 癌の臨 床 22(12)：906 909，1976.

16) Edward B, Kampsen MD, Nirmala Jager MD : Squamous cell carcinoma of the thyroid : a report of two cases. Journal of Surgical Oncology $9: 567 \sim 578,1977$.

原稿到着：昭和59年 9 月 14 日 別刷請求先：大平真司 厂564 大阪府吹田市片山町 2 丁目 13 番 20 号 市立吹田市民病院耳鼻咽喉科 